\title{
Assessing the significance of wet-canopy evaporation from forests during extreme rainfall events for flood mitigation in mountainous regions of the UK
}

\author{
Trevor Page ${ }^{1}$, Keith Beven ${ }^{1}$, Nick Chappell ${ }^{1}$, Ann kretzschmar ${ }^{1}$, and Barry Hankin ${ }^{2}$ \\ ${ }^{1}$ Lancaster University \\ ${ }^{2}$ JBA Consulting
}

May 15, 2020

\begin{abstract}
There is increased interest in the potential of tree planting to help mitigate flooding using nature-based solutions or natural flood management. However, many publications based upon catchment studies conclude that, as flood magnitude increases, benefit from forest cover declines and is insignificant for extreme flood events. These conclusions conflict with estimates of evaporation loss from forest plot observations of gross rainfall, throughfall and stem flow. This study explores data from existing studies to assess the magnitudes of evaporation and attempts to identify the meteorological conditions under which they would be supported. This is achieved using rainfall event data collated from publications and data archives from studies undertaken in temperate environments around the world. The meteorological conditions required to drive the observed evaporation losses are explored theoretically using the Penman-Monteith equation. The results of this theoretical analysis are compared with the prevailing meteorological conditions during large and extreme rainfall events in mountainous regions of the UK to assess the likely significance of wet canopy evaporation loss. The collated dataset showed that Ewc losses between approximately 2 and $38 \%$ of gross rainfall (1.5 to $39.4 \mathrm{~mm} \mathrm{~d}-1$ ) have been observed during large rainfall events (up to $118 \mathrm{~mm}$ d-1) and limited data for extreme events (>150 mm d-1). Event data greater than $150 \mathrm{~mm}$, where duration was not reported, showed similarly high percentage evaporation losses. Theoretical estimates of wet-canopy evaporation indicated that, to reproduce these high losses, relative humidity and the aerodynamic resistance for vapour transport needed to be within an envelope of approximately 90 to $97.5 \%$ and 0.5 to $2 \mathrm{~s} \mathrm{~m}-1$ respectively. Surface meteorological data during large and extreme rainfall events in the UK suggest that conditions favourable for high wet-canopy evaporation are not uncommon and indicate that significant evaporation losses during large and extreme events are possible but not for all events and not at all locations. Thus the disparity with the results from catchment studies remains.
\end{abstract}

\section{Keywords}

Wet-canopy evaporation; interception loss; extreme events; Natural Flood Management; meteorological controls; complex terrain; upland UK

\section{Introduction}

Recently in the UK, and elsewhere, there is increased interest in 'natural flood management' (NFM) or 'nature-based solutions' for flood peak mitigation (Dadson et al ., 2017; Environment Agency, 2018; Jongman, Winsemius, Fraser, Muis, \& Ward, 2018; Lane, 2017; Wingfield, et al ., 2019; World Bank, 2017). Tree planting may be one intervention that has the potential for flood peak reduction through: 1. increased soil infiltration capacity; 2. enhanced soil drying resulting from transpiration; 3. increased ground-surface roughness and 4. enhanced wet-canopy evaporation $(E w c)$. However, some studies suggest that the positive effects of tree cover on flood peaks declines as event magnitude increases, such that it is likely to be 
insignificant for large and extreme flood events (e.g. Bathurstet al ., 2018; Dadson et al ., 2017; Robinson \& Newson, 1986; Stratford et al ., 2017). These results suggest, implicitly, that Ewc is insignificant during large and extreme events.

For paired grassland and forest catchments on the Plynlimon massif (UK), Kirby, Newson, \& Gillman (1991, p60) observed, using flood frequency analysis, that mature conifer cover had little or no effect on the magnitude of peak flows. They showed, using chronological pairingof flood peaks, that very small hydrograph peaks were consistently greater from the grassland catchment compared to the forested catchment and that moderately sized event hydrographs showed no significant difference. At another paired forest and grassland study at Coalburn, Northern England, Bathurst et al . (2018) reported that forests can reduce flood peaks for small to moderate events but that hydrograph responses tend to converge at extreme events. Bathurst et al.(2011) explicitly tested the hypothesis: as the size of the hydrological event increases, the effect of forest cover becomes less important ; they concluded, for a number of study sites across Latin America, that forests do not eliminate floods and are unlikely to reduce significantly peak flows generated by extreme rainfall. Bathurstet al. (2011) however acknowledged that their analyses were based on relatively short periods with few extreme events such that conclusive support for the test hypothesis is still lacking.

Recent NFM-related literature reviews of forest effects on flood peaks support the idea of a diminishing effect with event magnitude. Stratfordet al. (2017) carried out a systematic review of studies to answer the question: Do trees in UK-relevant river catchments influence fluvial flood peaks? Their review focussed directly on the magnitudes of flood peaks rather than on individual hydrological processes and they concluded that the evidence is uncertain for the impact of increasing tree cover on large floods but it is consistent in showing increasing tree cover reduces small floods. Dadson et al . (2018) also reviewed evidence of the effects of forest cover and reported the findings of a number of studies; they recognised that forest management practices complicate determination of forest effects but that under sustained winter rainfall, soil saturation will occur and little mitigation of high flood flows would be expected.

From a process point of view, the benefits of increased infiltration rates and drier antecedent soil moisture conditions are likely to diminish with increasing event magnitude (Calder \& Aylward, 2006; Lull and Reinhart 1972; Pereiea, 1989); it is also likely that that boundary layer vapour pressure deficits, which exert a strong control onEwc, are likely to decrease during large and extreme rainfall events but the extent to which they decrease across large areas is not well known. The studies cited above did not explicitly included evidence from forest plot studies which estimate Ewc in a more direct way using a canopy water balance (described below), perhaps because only very few studies report Ewc for large or extreme events; they primarily considered the detection of hydrograph change from catchment studies globally.

Worldwide, catchment studies taken as a whole provide conflicting results regarding effects on large flood peaks; compare for example Jones \& Grant (1996), Thomas and Megahan (1998) and Beschta et al ., 2000. Many studies have found that the magnitudes or frequencies of large flood peaks are changed significantly by afforestation or forest harvesting (e.g. Alila et al ., 2009; Belmar et al ., 2018; Fahey and Payne, 2017; Guillemette, Plamondon, Prévost \& Lévesque, 2005; Jones \& Grant, 1996; López-Moreno et al., 2006); many do, however, show decreasing effects on flood peak as event magnitude increases or no significant change (Beschta et al ., 2000, Birkinshaw et al ., 2014; Robinson \& Newson, 1986; Thomas and Megahan, 1998; Whitehead and Robinson, 1993; Newson \& Calder, 1989). Uncertainties associated with catchment studies of hydrograph change, particularly for extreme events, can be very large (Bathurst et al ., 2018; Beschta et al ., 2000; Carrick et al ., 2018; Dadson et al ., 2017). Underlying signals of change associated with specific processes (e.g. evaporation or infiltration) can also be obscured by effects resulting from forestry practices, such as road construction, drainage or harvesting method (Bathurst et al ., 2018; Beschta et al ., 2000; Jones \& Grant, 1996; Guillemetteet al ., 2005; Robinson \& Newson, 1986; Thomas and Megahan, 1998). These factors combined with limited observations for extreme events (Lewis, Reid \& Thomas, 2010) mean that simple conclusions regarding forest effects on large or extreme flood peaks cannot be made (Andreassian, 2004; Carrick et al . 2017).

\subsection{Forest plot studies of wet-canopy evaporation: losses during large and extreme rainfall}




\section{events}

Forest plot studies estimate Ewc, using a canopy water balance (CWB), as the difference between the gross rainfall (??) incident upon a vegetation canopy and the fraction of ?? that reaches the ground asnet rainfall $(\mathrm{Pn})$. Net rainfall comprises rainfall that bypasses or drips from the canopy (throughfall : $T F$ ) and that which flows via stems and trunks (stem flow : $S F$ ). As noted above, very few studies have focused on CWB estimatedEwc during large $\left(>50 \mathrm{~mm} \mathrm{~d}^{-1}\right.$ of ??) or extreme $\left(>150 \mathrm{~mm} \mathrm{~d}^{-1}\right.$ of ??: Collier, Fox \& Hand, 2002) rainfall events. A notable exception is the work of Keim, Skaugset, Link and Iroume (2004) who report Ewc losses above 30\% of ?? at temperate sites in Chile and Northwest USA. Equally high Ewc losses during large magnitude rainfall events at other locations with a temperate climate have been reported (e.g. see Deguchiet al ., 2006 and Hashino et al ., 2002). Taken at "face value", these Ewc losses appear to be potentially significant in the context of flooding: removal of such large fractions of event rainfall from a catchment system are likely to have a significant effect on a flood hydrograph where tree planting covers a large proportion of a catchment (Hankin et al ., 2017). Consequently, there is an apparent disparity between the publications which conclude that forest effects on flood peaks are likely to be small or insignificant for large and extreme events and the CWB observations from forest plot studies.

The significance of forest $E w c$ for flood mitigation depends upon the difference in $E w c$ between a given forest canopy and another land cover. For example, moorland vegetation species such as Heather (Calluna vulgaris ) tend to have long-termevapotranspiration losses approximately $30 \%$ to $60 \%$ of that for tall forests and short semi-natural grasses lose around 10 to $40 \%$ of that for forests (e.g. Calder, 1976, Calder \& Newson, 1979; Calder et al ., 1981). However, as most comparative studies derive estimates from catchment or lysimeter water balances over relatively long periods, and do not separate Ewc and transpiration losses, these estimates are of limited use when considering individual events. Additionally, evaporation from a forest understorey or soil litter layer can be significant (Bulcock \& Jewitt 2012; Carlisle et al ., 1967; Gerrits et al ., 2007, 2010) and effectively increase the difference in Ewc loss (e.g. between forest and grass). We therefore assume that Ewc losses from tall canopies are likely to be significantly higher than for short vegetation under meteorological conditions favourable for wet-canopy evaporation and, consequently, that the absolute magnitude of Ewc from tall forest canopies is of primary relevance here. Thus it is important to determine the full extent of evidence for significant $E w c$ from forest canopies during large and extreme rainfall events as well as an understanding of the meteorological conditions under which significant losses might be supported.

\subsection{Aim and objectives of this study}

This study focuses on Ewc from forest canopies during large and extreme rainfall events. We use the Cumbrian Mountains, UK, as a focus for some of our analyses as large catchment-scale hydrological simulations of broad-scale tree planting are required. These simulations are designed to inform UK policy on the most effective methods of NFM. To inform these simulations, pertinent event-scale $E w c$ data from temperate sites around the world are collated and are contextualised using UK meteorological conditions via theoretical analyses. In the UK, large and extreme rainfall events primarily occur as long-duration autumn and winter storms when forest canopies can be continually wet, solar radiation is low and Ewc will dominate evaporative losses (Calder, 1990); these events are the focus of this study rather than extreme summer convective storms.

Our specific objectives are:

Objective 1 - to collate all available Ewc data from UK-relevant event-scale forest plot studies to quantify the magnitude and range of observed losses, particularly during large $\left(>50 \mathrm{~mm} \mathrm{~d}^{-1}\right)$ and extreme $(>150 \mathrm{~mm}$ $\mathrm{d}^{-1}$ ) rainfall events;Objective 2 - to explore the meteorological conditions consistent with the magnitudes of Ewc losses from Objective 1 using the Penman-Monteith equation;Objective 3 - to examine meteorological data from Cumbria and other mountainous regions of the UK during large and extreme rainfall events and to compare with the findings of Objective 2;Objective 4 - to discuss the implications of the findings from objectives 1 to 3 for estimating Ewc across large catchments in complex terrain.

\section{Methods}




\section{Study area}

The primary area of interest for this study, Cumbria, Northwest England (Figure 1) where the Q-NFM project (http://www.lancaster.ac.uk/lec/sites/qnfm) is tasked with simulating the effects of broad-scale tree planting scenarios on flood hydrographs using a catchment hydrological model. The study catchments are within a mountainous area where there have been 4 major flood events in the last 15 years. Cumbria, as for many mountainous regions of the UK, is situated towards the west coast and hence strongly influenced by temperate maritime airflows from the Atlantic Ocean. Mountainous regions of the UK are areas of extremely complex topography which, in combination with the predominant airflow, gives rise to orographically-influenced and spatially heterogeneous meteorological patterns (Blackie and Simpson, 1993; Ferranti, Whyatt, \& Timmis, 2009, Mayes, 2013). Annual rainfall is generally high; for example, across Cumbria the long-term annual average rainfall ranges from below $1000 \mathrm{~mm} \mathrm{yr}^{-1}$ on the coast and in areas of rain shadow to greater than $3500 \mathrm{~mm} \mathrm{yr}^{-1}$ across the highest mountains. Given there are no CWB Ewc data for this study area we consider other mountainous sites in the UK (Figure 1) and other temperate locations around the world.

\subsection{Observed event $E w c$ estimates from forest plot studies in temperate locations}

Studies relevant to UK conditions with forest plot CWB Ewcobservations were identified. Relevant studies were defined climatologically using the revised Koppen climate classification (Chen \& Chen, 2013) with the recognition that the classification provides general climatic classes within which there is a large degree of variability. Although this variability exists, Koppen climate classifications were used with the rationale that hydrometerological conditions will have similarities to those of UK mountainous regions during large and extreme rainfall events. The specific classifications deemed acceptable for the purposes of this study were: Cfa (mild temperate; fully humid; hot summer), Cfb (mild temperate; fully humid; warm summer), Cfc (mild temperate; fully humid; cool summer), Csb (mild temperate; dry summer; warm summer), Dfb (snow; fully humid; warm summer), Dfc (snow; fully humid; cool summer), Dfd (snow; fully humid; cold summer): the classifications $\mathrm{Cfb}$ and $\mathrm{Cfc}$ encompass all mountainous regions of the UK. For the climate classes where snow can form a significant part of winter precipitation (i.e. Dfb, Dfc and Dfd), care was taken not to include data affected by snow falls: in most cases this was already carried out in the original study.

From the studies identified as relevant (Table Supp. 1), only CWBEwc observations reported on a rainfall event basis or as a daily total were collated for analyses. For consistency, events reported to be over 24 hours (but no more than 48 hours) duration were standardised by calculating a normalised 24-hour rainfall (i.e. $\left.P g=24\left(\frac{\mathrm{Pe}}{\mathrm{De}}\right)\right)$ wherePe is the total event precipitation and De is event duration in hours): note that, in the text below, ?? relates to a daily or normalised daily total rainfall unless otherwise stated. It is accepted that using daily observations is somewhat artificial in as much as the duration of rainfall events may be truncated where they span multiple days; it is also recognised that both daily and event data may include periods without rain. Event-based data where event duration was not reported were also collated and are presented separately.

Data were gathered using values provided in tables or by digitising data presented as figures in published material and by abstracting data from field log sheets; in the case of Aussenac (1968) and Reynolds and Henderson (1967) Pg-Ewc relationships were digitised. Where observations were obtained from digitised figures, and where there were many data points, obscured or overlapping data will have resulted in some values not being included; these data were, however, invariably for relatively low ?? magnitudes. In some cases, the dates associated with individual rainfall events were not provided in the published material, which

does not allow separation by season (or by leafed or leafless period for deciduous species). Furthermore, as event data were limited and data for deciduous forest plots were very few, all events irrespective whether they were evergreen or deciduous were combined for the comparison with theoretical estimates, but are identified separately in figures.

\subsection{Theoretical Ewc estimates}

\subsubsection{Exploring the drivers of observed Ewc losses using the Penman-Monteith equation}


To explore the meteorological conditions required for consistency with observed Ewc losses, a broad range of Ewc estimates were made using the Penman-Monteith equation (Monteith, 1965 ;Eqn. 1); estimates were made using stratified samples from ranges of relative humidity ( $85 \%$ to $100 \%$; expressed via $\mathrm{e}_{z}$ where $\mathrm{Tz}$ is assumed to be $\left.10^{\circ} \mathrm{C}\right)$ and aerodynamic resistances $\left(0.5 \mathrm{~s} \mathrm{~m}^{-1}\right.$ to $\left.12 \mathrm{~s} \mathrm{~m}^{-1}\right)$. This analysis creates a response surface where different combinations of meteorological variables that lead to similar Ewc losses can easily be visualised. The Penman-Monteith equation takes the form:

$\lambda E_{\mathrm{PM}}=\frac{\Delta_{e} H+\rho_{a} c_{p}\left(e_{s}(\mathrm{Tz})-e_{z}\right) / r_{a} s}{\Delta_{e}+\Upsilon\left(1+r_{g} / r_{a} s\right)}(1)$

where $\lambda$ is the latent heat of vaporisation $\left(\mathrm{J} \mathrm{kg}^{-1}\right), E_{\mathrm{PM}}$ is the evapotranspiration rate $\left(\mathrm{kg} \mathrm{m}^{-2} \mathrm{~s}^{-1}\right), \Delta_{e}$ is the slope of the saturation vapour pressure curve versus temperature relationship $\left(\mathrm{Pa} \mathrm{K}^{-1}\right)$ at temperature, $\mathrm{Tz}$, where $z$ is the observation height in metres, $H$ is the total energy available for evaporation $\left(\mathrm{J} \mathrm{m}^{-2}\right), \rho_{a}$ is the density of air at $\mathrm{Tz}\left(\mathrm{kg} \mathrm{m}^{-3}\right), c_{p}$ is the specific heat capacity of air $\left(\mathrm{J} \mathrm{kg}^{-1} \mathrm{~K}^{-1}\right), e_{s}(\mathrm{Tz})$ is the saturation vapour pressure at $\mathrm{Tz}, e_{z}$ is the actual vapour pressure at $z, \gamma$ is the psychrometric constant $\left(\approx 66 \times 10^{-3} \mathrm{~Pa}\right.$ $\mathrm{K}^{-1}$ ) and $r_{a_{-}} s$ and $r_{g}$ are the resistance to the aerodynamic exchange for scalars (sensible heat and vapour) and surface resistances respectively $\left(\mathrm{s} \mathrm{m}^{-1}\right)$. Note that in all calculations made here, the canopy is assumed to be wet and $r_{g}$ is assumed to be zero such that the term $\left(1+r_{g} / r_{a} s\right)$ disappears (Stewart, 1977; VanDijk et al., 2015). The total energy available $(H)$ was assumed to be the approximate net radiation $\left(R_{n}\right)$ for a cloudy day during winter in Northern England: nominally $2.5 \mathrm{MJ} \mathrm{m}^{-2} \mathrm{~d}^{-1}$.

\subsubsection{Estimates of aerodynamic exchange and $\mathrm{E}_{\mathrm{PM}}$ using meteorological observations}

To explore the potential for Ewc across mountainous regions of the UK during large and extreme rainfall events, $E_{\mathrm{PM}}$ was calculated using meteorological data for 17 sites (Figure 1a and Table Supp. 2) using Eqn. 1. The aerodynamic resistance for momentum $\left(r_{a_{-}} m\right)$ was estimated using Eqn. 2:

$r_{a \_} m=\frac{\ln \left(\frac{z-d}{z 0-m}\right)^{2}}{\kappa^{2} U_{z}}(2)$

where $z$ is the wind speed observation height, $d$ is the zero-plane displacement, $z 0 \_m$ is the roughness length for momentum (all in metres), $U_{\mathrm{z}}$ is the wind speed $\left(\mathrm{m} \mathrm{s}^{-1}\right)$ at $z$ and $\kappa$ is the dimensionless von Karman constant $(\approx 0.41)$. The canopy height $(\mathrm{Zc})$ was arbitrarily assumed to be $20 \mathrm{~m}, d$ to be $0.75(\mathrm{Zc})$ and $z 0 \_m$ as $0.1(\mathrm{Zc})$ in accordance with Szeicz, Endrodi and Tajhman (1969) and Rutter, Robins, Morton and Kershaw (1972). However, studies have shown an enhancement of exchange compared to estimates assuming these approximations for $z 0 \_m$ (e.g. Holwerda et al ., 2012). Enhancement of momentum exchange has been observed both for tall canopies and in complex terrain owing to breakdown of theoretical vertical logarithmic wind profiles (Cellier and Brunet, 1992; Raupach, 1979; Simpson, Thurtell, Neumann, Den Hartog, \& Edwards, 1998). For the indicative calculations made here, where $\mathrm{z}<\mathrm{Zc}$, wind speed was extrapolated to Zc using a logarithmic wind profile relationship. Wind speed observations used here are taken over short grass surfaces and extrapolated to hypothetical canopy height as if the logarithmic profile assumption is valid. It is recognised that this may not be the case in complex terrain but, as the degree of enhancement of momentum exchange is not easily estimated and because the calculations made here are purely indicative no enhancements have been made for $r_{a_{-}} m$.

It is often assumed that $r_{a_{-}} s$ is equal to $r_{a_{-}} m$, but this assumption can to lead to considerable error (Brutstaert, 1982, p62) owing to so-called excess resistance for scalars. Excess resistance occurs because pressure forces associated with form drag increase momentum exchange, but not scalar exchange and because of differences in source and sink distributions for these entities (Brutstaert, 1982; Moors, 2012; Simpson, et al ., 1998; Stewart \& Thom, 1973). Although there can be differences between the magnitude of exchange for different scalars, we assume that the exchange of heat and vapour are equal for the purposes of this study and hence only explore differences between the magnitude of scalar exchange compared to the exchange of momentum. Aerodynamic exchange estimated using Eqn. 2 is more sensitive to the value of $z 0$ than it is to the value of $d$ (Gash, Wright \& Lloyd, 1980). The value of $z 0$ has been shown to vary significantly with wind speed for forest canopies, whilst $d$ tends to remain relatively constant (Bosvelt, 1999; Szeicz, \& Endrodi, 1969). Consequently, $d$ is fixed as specified above for all calculations made here and it is assumed that the 
primary differences between $r_{a \_} s$ and $r_{a_{-}} m$ are driven by differences in $z 0_{-} m$ and $z 0_{-} s$. It is worth noting that $d$ may vary significantly for very sparse canopies or for deciduous canopies during the leafless period (Brutstaert, 1982, p116; Dolman, 1986).

The ratio of $z 0 \_s / z 0 \_m$ used in previous studies varies over approximately an order of magnitude as it is influenced by canopy roughness, canopy density, atmospheric stability and wind speed (Bosvelt, 1999; Brutstaert, 1982, p114; Lalic, Mihailovic, Rajkovic, Arsenic, \& Radlovic, 2003; Raupach, 1979; Thom, Stewart, Oliver \& Gash, 1975). The sensitivity of $r_{a_{-}} s$ and $E_{\mathrm{PM}}$ to the ratio $z 0_{-} s / z 0 \_m$ is explored here using three scenarios:

Scenario $1-z 0 \_s / z 0 \_m=1.0$; i.e. $z 0 \_s=0.1(\mathrm{Zc})$;

Scenario 2 - $z 0 \_s / z 0 \_m=0.5$; i.e. $z 0 \_s=0.05(\mathrm{Zc})$;

Scenario $3-z 0 \_s / z 0 \_m=0.1$; i.e. $z 0 \_s=0.01(\mathrm{Zc})$.

It is likely that vapour pressure deficit (also expressed as relative humidity, $R H$ ) observations over grassland meteorological observation sites are likely to be lower than those over an adjacent forested area (e.g. see Pearce, Gash, \& Stewart 1980). No attempt has been made to correct $R H$ observations for this study owing to the complexities associated with such a correction and the indicative nature of our calculations; this is also the case for Tz which is likely to be lower above a forest canopy (Rutter, 1967). Additionally, Eqn. 2 is strictly only valid for neutral atmospheric conditions (Szeicz, and Endrodi, 1969) but corrections for non-neutral conditions are often assumed to be insignificant during rainfall (e.g. Morton, 1984; van Dijk et al ., 2015) and we assume they are negligible here.

\section{Results and discussion}

\subsection{Objective 1: canopy water balance observations of wet-canopy evaporation during large} and extreme events

The data search provided observations from 18 study sites that have CWB observations of Ewc for large storms associated with either daily or normalised event ?? (see Table Supp. 3): none of the events were extreme events based upon the classification employed $\left(>150 \mathrm{~mm} \mathrm{~d}^{-1}\right)$. From these sites 1387 ??-Ewc pairs were obtained with a maximum ?? of approximately $118 \mathrm{~mm}$. Only 35 of these pairs were associated with ?? observations over $50 \mathrm{~mm} \mathrm{~d}^{-1}$ (Table Supp. 3). In absolute terms, the Ewcdata include some high magnitudes; they include a maximum Ewcloss of $39.4 \mathrm{~mm} \mathrm{~d}^{-1}$ with 40 events where Ewcloss was over $10 \mathrm{~mm} \mathrm{~d}^{-1}$. When Ewc is expressed as a percentage of ?? (\%Ewc), there is a decreasing trend in \%Ewc as ?? increases (Figure 2). This pattern of declining relative loss has been shown previously in many studies (e.g. Iroume \& Huber, 2002; Bulcock \& Jewitt, 2012), including the seminal review by Horton (1919). From these 1387 data pairs, 58 gave a negative $\% E w c$ and 25 were over $100 \% E w c$; these data lie predominantly at low ?? magnitudes and are not presented in Figure 2 and can be caused by error, sampling truncation of events and fog-drip and will be incorporated into uncertainty analysis in future work. The subset of the data from UK catchments are overlain by green filled-circles in Figure 2; the individual numbered events where ?? > $50 \mathrm{~mm}$ are specified in Table Supp. 3. These UK data tend to span the higher rates of \%Ewc for higher ?? magnitudes and include absolute losses up to $26.3 \mathrm{~mm} \mathrm{~d}^{-1}$. The few data which are associated with plots under entirely deciduous species are highlighted as orange-filled circles in Figure 2: only one data pair was associated with ?? greater than $50 \mathrm{~mm}$ per day of which approximately $11 \%$ was lost to Ewc. The degree to which \%Ewc continues to decrease with increasing ??, or whether it has reached a stable range is unclear from Figure 2 given the few data available at higher ?? magnitudes. This is important as the highest ?? from these data is significantly lower than extreme daily rainfall totals recorded in the Cumbrian Mountains which has been observed to be as high as $341 \mathrm{~mm}$ in a 24-hour period at Honister Pass, Cumbria (Met. Office 2018) which led to widespread severe flooding.

Observations associated with studies where no event duration data were available provided 1144 ??-Ewc pairs including some high \%Ewc losses (ranging from approximately 7 to $35 \%$ ) for very large ?? values (up to $435 \mathrm{~mm}$ : see Table Supp. 2). These data are plotted as black filled-circles in Figure 3 with plots under 
entirely deciduous species highlighted as orange-filled circles. Although these data are difficult to compare to the daily or normalised daily data, the high losses observed are significant given that these are potentially extreme events, likely to be of maximum 3 or 4 days in duration and hence serve as a useful reference. An exception to this rule are the data from Deguchi, Hattori, \& Park (2006) where it is possible that observations were made over a period of up to 2 weeks; however, the largest event from their study (which was identified as taking place on September 11-12 $2^{\text {th }}, 2000$ ) deposited $347 \mathrm{~mm}$ ??, with $14 \%$ of this being lost to Ewc. The magnitude of the losses from these non-normalised events are qualitatively consistent with the normalised events presented in Figure 2.

The data for large and extreme events presented in Figures 2 and 3 show a large range of Ewc loss: approximately 2-38\% of ??. These losses are apparently significant in the context of flood mitigation with absolute losses of up to approximately $40 \mathrm{~mm} \mathrm{~d}^{-1}$. Unfortunately, concurrent meteorological observations were generally not reported for events greater than $50 \mathrm{~mm} \mathrm{~d}^{-1}$ : concurrent observations were only available for 4 events at one site (Dolydd, mid-Wales; events 7-10, Table Supp. 3). This lack of meteorological data means that it is, in general, not possible to link the observedEwc losses with the magnitude of important meteorological variables which would allow some form of model calibration. Model calibration of this kind is problematic and also needs to include canopy storage limitation of Ewc (see Calder, 1977).

\subsection{Objective 2: estimation of meteorological conditions consistent with observed Ewc losses}

\subsubsection{The likely magnitude of meteorological controls driving observed Ewc losses}

Penman-Monteith potential evaporation estimates, $E_{\mathrm{PM}}$, were made across the ranges described in section 2.3 above. A representation of how $E_{\mathrm{PM}}$ varies with $r_{a_{-}} s$ and saturation vapour pressure deficit (expressed as $R H$ ) is shown in Figure 4. With respect to Objective 2, given the Penman-Monteith equation and the assumptions of the analysis, to achieve the higher end of absoluteEwc losses observed $\left(\approx 20\right.$ to $\left.40 \mathrm{~mm} \mathrm{~d}^{-1}\right)$ either fairly low $R H$ or very low $r_{a_{-}} s$ values are required, or an equivalent combination of $R H$ and $r_{a_{-}} s$. Relative humidity needs to be below approximately $90 \%$ where $r_{a_{-}} s$ is around $2 \mathrm{~s} \mathrm{~m}^{-1}$ or around $97.5 \%$ as $r_{a_{-}} s$ approaches $0.5 \mathrm{~s} \mathrm{~m}^{-1}$. Figure 4 also highlights how $E_{\mathrm{PM}}$ becomes increasingly sensitive to small changes in $r_{a} s$ at lower values: i.e. for higher wind speeds and rougher canopies (as previously shown by Beven, 1979 \& Dolman, 1986). At these low $r_{a_{-}} s$ values, $E_{\mathrm{PM}}$ is also considerably more sensitive to changes in $R H$ , and even at relatively high $R H$, the potential for significant evaporation loss exists. Owing to this extreme sensitivity at low $r_{a_{-}} s$ values, uncertainties associated with estimating effective $r_{a_{-}} s$ values and $R H$ become critical in the interpretation of the results presented here and are discussed in more detail below.

3.3 Objective 3: Meteorological conditions and wet-canopy evaporation estimates for mountainous regions of the UK

\subsubsection{Penman-Monteith wet-canopy evaporation estimates for mountainous regions of the UK}

Estimates of $E_{\mathrm{PM}}$ made using the meteorological data for the 17 sites specified in section 2.3 .2 show that, given the assumptions of our analysis, within-storm conditions for potentially high Ewcloss are possible in mountainous regions of the UK. High wind speeds and relatively low $R H$ can prevail during days with significant rainfall. This is illustrated in Figure $5 \mathrm{a}$ where hourly average $r_{a_{-}} s$ versus $R H$ data are plotted for the sites identified in Table Supp. 2. The points plotted in Figure 5a relate to hourly periods within a 24-hour period with over $50 \mathrm{~mm}$ of rainfall and where the hourly rainfall total was above zero. The estimates of $r_{a} s$, using the 3 scenarios for $z 0_{-} s$ as described above, are represented by: black filled-circles for $z 0 \_s=0.1(\mathrm{Zc})$, green filled-circles for $z 0 \_s=0.05(\mathrm{Zc})$ and red filled-circles for $z 0 \_s=0.01(Z c)$. Figure 5 a demonstrates that very low $r_{a \_} s$ values can occur within 24-hour periods where ?? is greater than 50 $\mathrm{mm}$ and that the majority of these periods were associated with $R H$ values predominantly in the range $85 \%$ to $98 \%$ which shows significant overlap with the conditions required for significant $E_{\mathrm{PM}}$ estimated for Objective 2. Meteorological conditions during more extreme events ( $>150 \mathrm{~mm}$ in 24-hours and where the hourly rainfall $>0$ ), also shown in Figure 5a as diamonds; this figure suggests that, particularly for $\mathrm{RH}$, conditions can be even more favourable for high $E_{\mathrm{PM}}$ but are associated with the caveat that there are relatively few observations during very few events of this magnitude. The potential for high $E_{\mathrm{PM}}$ is shown 
more explicitly in Figure 5b (which uses the same data as Figure 5a). The difference between the estimates made using the $3 z 0 \_s$ highlights again how sensitive $E_{\mathrm{PM}}$ magnitude is to $z 0 \_s$. However, fairly high rates of $E_{\mathrm{PM}}$ are estimated for all $z 0 \_s$ scenarios although the $z 0 \_s=0.01(\mathrm{Zc})$ scenario is mainly limited to losses of below $12 \mathrm{~mm} \mathrm{~d}^{-1}$.

\subsubsection{Meteorological conditions during extreme events across Cumbria}

Figures 6 and 7 (and Figures Supp. $1 \&$ 2) show time series of meteorological variables during the 4 extreme Cumbrian rainfall events that occurred since 2005. Each event was associated with a frontal system, the 2005, 2009 and 2015 events being classified as atmospheric rivers, where enhanced horizontal water vapour transport from the Atlantic Ocean occurs (Lavers et al ., 2011, 2013; Matthews, Murphy, McCarthy, Broderick, \& Wilby, 2018). The meteorological time series show that, at many of the locations, during the main periods of rainfall (indicated by the grey shaded area in Figures 6b, 7b, Supp. 1b \& 2b) relatively low $R H$ (in the context of the results presented above) occurs along with high wind speeds (Figures 6a, 7a, Supp. 1a \& 2a) and an increase in air temperature (Figures 6, 7c, Supp. 1a \& 2a). A notable exception to these general patterns are the differences in $R H$ between sites for the 2009 event where Keswick and Walney were at approximately 90-95\% $R H$ during the main rainfall period but the Shap and Walney sites were at, or close to, saturation. This was also the case at the higher elevation site of Great Dun Fell where the wind speeds were very high but the $R H$ remained at $100 \%$ throughout the entire period of rainfall (Figures 7a and 7b respectively). Similarly, but for the 2015 flood event, in a clearing in Gisburn Forest, Lancashire the $R H$ remained very high or at saturation for a large part of the storm (Figure $7 \mathrm{~b}$ ). There is also consistency in that Keswick, which is a less exposed site at relatively low elevation on the lee side of one of the highest regions of mountains, tends to have lower wind speeds, higher temperatures and lower $R H$ than the other locations during all extreme events considered (Figures 6, 7 and Supp. $1 \&$ 2). It is worth highlighting the caveat that the Keswick, Shap and Warcop sites are located on the leeward side (relative to the dominant south westerly flows) of mountain ridges such that the observed favourable conditions for Ewc loss shown are not necessarily representative across the region as a whole: as shown by the less favourable conditions for Ewc loss at Gisburn Forest and Great Dun Fell. These results show that even during the 4 most extreme events in Cumbria over the last 15 years, high windspeeds and surprisingly low $R H$ provide favourable conditions for significant $E w c$ loss at some locations. Consequently the need to estimate $E w c$ losses across large catchments, particularly in complex mountainous terrain, requires a representation of the spatial variability of meteorological controls which will be challenging where only sparse meteorological observations are available.

\subsection{Objective 4: implications for estimating the magnitude of Ewc across large catchments in complex terrain}

The results from objectives 1 to 3 show that Ewc losses up to approximately $40 \mathrm{~mm} \mathrm{~d}^{-1}$ have been observed at temperate sites around the world and that meteorological conditions that have the potential to give rise to such large losses can exist in mountainous regions of the UK. However, these findings must be treated with caution because concurrent meteorological observations are rarely reported with CWB Ewc data, particularly during extreme events, and Penman-Monteith estimates are extremely sensitive toestimated aerodynamic exchange and small changes in $R H$ at the higher windspeeds that often prevail during the large rainfall events considered here. The analysis has also shown that both wind speed and $R H$ varies significantly with spatial location. Given that Ewc estimates are required for hydrological simulation of large catchments, a representation of this spatially variable control of Ewcmagnitude is required; it is not appropriate to sample a statistical distribution of Ewc loss generated from the worldwide observations of Ewc data (for a given gross rainfall total) as the autocorrelation of Ewc, controlled by autocorrelated meteorological variables, through sequences of real events is needed. With respect to this requirement, even a spatially sparse time series of meteorological observations contains important information describing temporal patterns of some of the primary controls onEwc and this information must be retained. Spatial interpolation and extrapolation from these sparse meteorological observations will inevitably be inherently uncertain but is an important prerequisite for appropriate estimation of Ewc losses. 
Although simple empirical models can be used to estimate Ewc where there is a scarcity of adequate meteorological data and knowledge of appropriate parameter values for more complex models (e.g. see Lu, McNulty \& Amatya, 1995), their use is limited as they may not explicitly include important meteorological controls. Consequently, the Penman-Monteith equation is still used to simulate evaporation from wetted surfaces in the majority of Ewc models (Muzylo et al ., 2009). Thus, Penman-Monteith equation remains a useful method to determine the potential for Ewc loss but the magnitude of any estimates made will be highly uncertain without meaningful calibration of critical and sensitive parameters such as $r_{a_{-}} s$. However, as there are so few Ewc data associated with concurrent meteorological observations, particularly large rainfall events, it is rarely possible to calibrate the parameters of the Penman-Monteith equation and any calibration would need to include the joint-calibration of parameters of an (e.g. Rutter-type) effective canopy store model (e.g. see Calder, 1977).

Our theoretical analyses show that it is possible to get a very wide range of Ewc estimates depending upon, in particular, the way that $r_{a} s$ is estimated. These analyses used 3 scenarios of $r_{a} s$ which were based upon a range of published values derived both directly from micrometeorological observations and via model calibration. Ratios of $z 0_{-} s / z 0 \_m$ have been reported to be: of the order 0.1-0.2 (Klingaman, Levia, \& Frost, 2007; Lankreijer, Hendriks, \& Klaassen, 1993); approximately 0.3-0.5 (Brutstaert, 1982, p114; Stewart \& Thom, 1973) and around 1 in some cases (Bosvelt, 1999; Gash, Valente, \& David, 1999; Moors, 2012). Significant uncertainties exist when estimating $r_{a_{-}} m$ and the relative magnitude of $r_{a_{-}} s$ compared to $r_{a} \ldots m$. When only momentum is considered, representing the degree of exchange is not simple as it has been shown to vary, and to be enhanced compared to theoretical estimates, in complex terrain and over tall canopies (Cellier \& Brunet,1992; Holwerda et al ., 2012); $r_{a_{-}} m$ also varies with canopy roughness and canopy density (Brutstaert, 1982, Fig. 5.1; Cellier \& Brunet,1992; Holwerda et al ., 2012) as well as atmospheric stability and wind speed (Bosvelt, 1999; Cellier \& Brunet,1992; Szeicz, \& Endrodi, 1969). The ratio $z 0 \_s / z 0 \_m$ also varies widely and with the same factors as $r_{a} m$ and current understanding of scalar exchange for tall canopies in complex terrain remains rudimentary (Belcher, Harman \& Finnigan, 2012). There are, however, a relatively large number of published studies which report $r_{a} m$ and $r_{a_{-}} s$ for various vegetation of differing roughness which may help elucidate the relevant range of $r_{a}{ }_{-} s$ for use in $E w c$ estimation for a given application: a review of these studies is, however, beyond the scope of this paper.

Given the need for interpolation and extrapolation from sparse meteorological data to estimate meteorological controls on Ewcspatially, uncertainties will be very large such that a scenario-based approach may be most appropriate. Any defined scenario will beconditional on the evidence base used in its development and any additional modelling assumptions. The conditionality of each scenario must be made explicit and each scenario can be associated with a confidence-weighting which can be propagated to simulation results. This will be the subject of future publications.

\section{Conclusions}

At temperate locations around the world, high wet-canopy evaporation losses have been observed from forests using canopy water balance methods during large and extreme rainfall events and are associated with significant variability. Wet-canopy evaporation of up to approximately $40 \mathrm{~mm} \mathrm{~d}^{-1}$ have been recorded for large rainfall events $\left(>50 \mathrm{~mm} \mathrm{~d}^{-1}\right)$ and across all events range between approximately 2 and $38 \%$ of gross rainfall. Taken at "face value" these evaporation losses are qualitatively significant in the context of flood mitigation resulting from tree planting. Theoretical wet-canopy evaporation estimates made using the Penman-Monteith model for large and extreme events in mountainous regions of the UK suggest consistency with these high observed losses but uncertainties associated with the estimation of, in particular, aerodynamic exchange are so large that this test of consistency remains weak. During 4 major flood events in the Cumbrian Mountains, UK, meteorological conditions were favourable for high rates of wet-canopy evaporation: high windspeeds prevailed and surprisingly low relative humidity was observed at some locations. Thus the disparity regarding the significance of wet-canopy evaporation for flood mitigation between conclusions based upon results from catchments studies of forest cover effects and results from forest plot studies remains.

Our results suggest that it is possible for high rates of Ewcover forest to occur during large flood events 
in mountainous regions of the UK but not in all locations and not for all events. To be able to determine the potential of tree planting scenarios on flood hydrographs using hydrological models, estimates of the spatial and temporal patterns of wet-canopy evaporation through sequences of rainfall events are needed. Appropriate estimates require simulation of the control imposed by meteorological variables on wet-canopy evaporation to be made necessitating interpolation and extrapolation from (normally) sparse meteorological observation sites. This is difficult to implement with any accuracy and the uncertainties associated with this step are compounded with the large uncertainties associated with the estimation of aerodynamic exchange with forest canopies such that wet-canopy evaporation estimates may be represented best as scenarios. Simulations must also be able to represent the limitation on evaporation imposed by storage on the surfaces of different vegetation canopies (e.g. between foliated and unfoliated deciduous trees) meaning that scenarios of parameterisations must be incorporated into the simulations. Simulation scenarios must be associated with a confidence weighting that can be propagated to simulation results as expressions of modelling uncertainty.

If the considerable uncertainties associated with estimating meteorological conditions and Ewc across large areas such are to be constrained, collection and analysis of a larger number of well-placed and well-distributed meteorological observations is required, combined with concurrent wet-canopy evaporation observations.

\section{Data Availability Statement}

For part of the data which are digitized from this work, data sharing is not applicable new data were created or analyzed in this study. Other data which has been newly gathered from historical archives requires the permission of the data holder.

\section{References}

Alila, Y., Kuraś, P.K., Schnorbus, M., \& Hudson, R. (2009). Forests and floods: A new paradigm sheds light on age-old controversies. Water Resources Research 45 . https://doi.org/10.1029/2008WR007207

Andre, F., Jonard, M., Jonard, F., \& Ponette, Q. (2011). Spatial and temporal patterns of throughfall volume in a deciduous mixed-species stand. Journal of Hydrology, 400(1-2) , 244-254. https://doi.org/10.1016/j.jhydrol.2011.01.037

Aussenac, G. (1968). Interception des précipitations par le couvert forestier, in: Annales Des Sciences Forestieres . EDP Sciences, 135-156.

Bathurst, J., Birkinshaw, S., Johnson, H., Kenny, A., Napier, A., Raven, S., Robinson, J., \& Stroud, R. (2018). Runoff, flood peaks and proportional response in a combined nested and paired forest plantation/peat grassland catchment. Journal of Hydrology 564, 916-927. https://doi.org/10.1016/j.jhydrol.2018.07.039

Bathurst, J.C., Iroume, A., Cisneros, F., Fallas, J., Iturraspe, R., Gavino Novillo, M., Urciuolo, A., de Bievre, B., Guerrero Borges, V., Coello, C., Cisneros, P., Gayoso, J., Miranda, M., \& Ramirez, M. (2011). Forest impact on floods due to extreme rainfall and snowmelt in four Latin American environments 1: Field data analysis. Journal of Hydrology 400 , 281-291. https://doi.org/10.1016/j.jhydrol.2010.11.044

Belcher, S.E., Harman, I.N., \& Finnigan, J.J. (2012). The Wind in the Willows: Flows in Forest Canopies in Complex Terrain, in: Davis, SH and Moin, P (Ed.), Annual review of fluid mechanics, 44, 479-504. https://doi.org/10.1146/annurev-fluid-120710-101036

Belmar, O., Barquín, J., Álvarez-Martínez, J.M., Peñas, F.J., \& Del Jesus, M. (2018). The role of forest maturity in extreme hydrological events. Ecohydrology 11, e1947. https://doi.org/10.1002/eco.1947

Beven, K. (1979). Sensitivity analysis of the Penman-Monteith actual evapotranspiration estimates. Journal of Hydrology 44 , 169-190. https://doi.org/10.1016/0022-1694(79)90130-6

Beschta, R.L., Pyles, M.R., Skaugset, A.E., \& Surfleet, C.G. (2000). Peakflow responses to forest practices in the western cascades of Oregon, USA. Journal of Hydrology, 233(1-4) , pp.102-120. 
Blackie, J., \& Simpson, T. (1993). Climatic variability within the Balquhidder catchments and its effect on penman potential evaporation.Journal of Hydrology 145 , 371-387. https://doi.org/10.1016/00221694(93)90064-G

Bosveld, F.C., 1999. Exchange Processes between a Coniferous Forest and the Atmosphere. Ph.D. thesis, Universiteit van Amsterdam, the Netherlands, $169 \mathrm{p}$.

Brutstaert, W. (1982). Evaporation into the atmosphere: theory history and applications. D. Reidel Publishing Company, London, England, 295p.

Bulcock, H.H., \& Jewitt, G.P.W. (2012). Field data collection and analysis of canopy and litter interception in commercial forest plantations in the KwaZulu-Natal Midlands, South Africa. Hydrology and Earth System Sciences 16 , 3717-3728. https://doi.org/10.5194/hess-16-3717-2012

Birkinshaw, S.J., Bathurst, J.C., \& Robinson, M. (2014). 45 years of non-stationary hydrology over a forest plantation growth cycle, Coalburn catchment, Northern England. Journal of Hydrology 519 , 559-573. https://doi.org/10.1016/j.jhydrol.2014.07.050

Calder, I.R., 1976. The measurement of water losses from a forested area using a "natural" lysimeter. Journal of Hydrology 30 , 311-325. https://doi.org/10.1016/0022-1694(76)90115-3

Calder, I. (1977). Model of transpiration and interception loss from a spruce forest in Plynlimon, Central Wales. Journal of Hydrology 33 , 247-265. https://doi.org/10.1016/0022-1694(77)90038-5

Calder, I.R. (1981). Report on collaborative project with the British Waterways Board on the effects of afforestation on the runoff from the catchments supplying the Crinan canal reservoirs (Report No. 1980/003 ). Institute of Hydrology, Wallingford, UK. 80p (accessed May 2018: http://nora.nerc.ac.uk/id/eprint/14633/1/N014633CR.pdf).

Calder, I.R. (1985). What are the limits on forest evaporation? - Comment. Journal of Hydrology 82 , 179-184. https://doi.org/10.1016/0022-1694(85)90053-8

Calder, I.R. (1990). Evaporation in the uplands. Chichester: John Wiley \& Sons Ltd, 148p.

Calder, I.R., Smyle, J., \& Aylward, B. (2007). Debate over flood-proofing effects of planting forests. Nature 450,945 . https://doi.org/10.1038/450945b

Carlisle, A., H. F. Brown, A., J. \& White, E. (1967). The Nutrient Content of Tree Stem Flow and Ground Flora Litter and Leachates in a Sessile Oak Woodland. The Journal of Ecology 55 , 615. https://doi.org/10.2307/2258413

Carrick, J., Abdul Rahim, M.S.A.B., Adjei, C., Ashraa Kalee, H.H.H., Banks, S.J., Bolam, F.C., Campos Luna, I.M., Clark, B., Cowton, J., Domingos, I.F.N., Golicha, D.D., Gupta, G., Grainger, M., Hasanaliyeva, G., Hodgson, D.J., Lopez-Capel, E., Magistrali, A.J., Merrell, I.G., Oikeh, I., Othman, M.S., Ranathunga Mudiyanselage, T.K.R., Samuel, C.W.C., Sufar, E.K., Watson, P.A., Zakaria, N.N.A.B., \& Stewart, G. (2019). Is planting trees the solution to reducing flood risks? Journal of Flood Risk Management 12, e12484. https://doi.org/10.1111/jfr3.12484

Cellier, P., \& Brunet, Y. (1992). Flux gradient relationships above tall plant canopies. Agricultural and Forest Meteorology 58 , 93-117. https://doi.org/10.1016/0168-1923(92)90113-I

Chappell, N.A. (2018a). Gross and net rainfall at Law Lysimeter on days with high rainfall and daily net rainfall observations (Stocks_raw_data_xlsx). Lancaster University, UK.

Chappell, N.A. (2018b). Gross and net rainfall at Dolydd on days with high rainfall and daily net rainfall observations (Dolydd_raw_data_xlsx). Obtained from Centre of Ecology and Hydrology raw data archive, Lancaster University, UK. 
Chen, D., \& Chen, H.W. (2013). Using the Köppen classification to quantify climate variation and change: An example for 1901-2010.Environmental Development 6 , 69-79. https://doi.org/10.1016/j.envdev.2013.03.007

Cisneros Vaca, C., van der Tol, C., \& Ghimire, C.P. (2018). The influence of long-term changes in canopy structure on rainfall interception loss: a case study in Speulderbos, the Netherlands.Hydrology and Earth System Sciences 22 , 3701-3719. https://doi.org/10.5194/hess-22-3701-2018

Collier, C.G., Fox, N.I. \& Hand. W.H. (2002). Extreme Rainfall and Flood Event Recognition. Contract Report FD2201, Report to Defra and the Environment Agency, 57p.

Crabtree, R., \& Trudgill, S. (1985). Hillslope hydrochemistry and stream response on a wooded, permeable bedrock - the role of stemflow. Journal of Hydrology 80 , 161-178. https://doi.org/10.1016/0022-1694(85)900794

Crockford, R., \& Richardson, D. (1990). Partitioning of rainfall in a eucalypt forest and pine plantation in Southeastern Australia. 1. Throughfall measurement in a eucalypt forest - effect of method and species composition. Hydrological Processes 4 , 131-144. https://doi.org/10.1002/hyp.3360040204

Crockford, R., \& Richardson, D. (2000). Partitioning of rainfall into throughfall, stemflow and interception: effect of forest type, ground cover and climate. Hydrological Processes 14 , 2903-2920. https://doi.org/10.1002/1099-1085(200011/12)14:16/17<2903::AID-HYP126>3.0.CO;2-6

Dadson, S.J., Hall, J.W., Murgatroyd, A., Acreman, M., Bates, P., Beven, K., Heathwaite, ... Wilby, R. (2017). A restatement of the natural science evidence concerning catchment-based 'natural'flood management in the UK. Proc. R. Soc. A $473,20160706$.

Deguchi, A., Hattori, S., \& Park, H.T. (2006). The influence of seasonal changes in canopy structure on interception loss: application of the revised Gash model. Journal of Hydrology 318 , 80-102.

Dolman, A.J. (1986). Estimates of roughness length and zero plane displacement for a foliated and non-foliated oak canopy. Agricultural and Forest Meteorology 36 , 241-248. https://doi.org/10.1016/01681923(86)90038-9

Dunin, F., Oloughlin, E., \& Reyenga, W. (1988). Interception loss from eucalypt forest - lysimeter determination of hourly rates for long-term evaluation. Hydrological Processes 2 , 315-329. https://doi.org/10.1002/hyp.3360020403

Eden, P.,\& Burt, S. (2010). Extreme monthly rainfall: November 2009. Weather 65 , 82-83. https://doi.org/10.1002/wea.568

Environment Agency (2019). Working with Natural Processes - Using the evidence base to make the case for Natural Flood Management. Hankin, B., Burgess-Gamble, L., Rose, S. Eds. Environment Agency, Bristol $29 \mathrm{p}$.

Fahey, B., \& Payne, J. (2017). The Glendhu experimental catchment study, upland east Otago, New Zealand: 34 years of hydrological observations on the afforestation of tussock grasslands. Hydrological Processes 31 , 2921-2934. https://doi.org/10.1002/hyp.11234

Ferranti, E.J.S., Whyatt, J.D., \& Timmis, R.J. (2009). Development and application of topographic descriptors for conditional analysis of rainfall. Atmospheric Science Letters 10 , 177-184. https://doi.org/10.1002/asl.228

Gash, J.H.C., Wright, I.R., \& Lloyd, C.R. (1980). Comparative estimates of interception loss from three coniferous forests in Great Britain. Journal of Hydrology 48 , 89-105. https://doi.org/10.1016/00221694(80)90068-2

Gash, J., Valente, F., \& David, J. (1999). Estimates and measurements of evaporation from wet, sparse pine forest in Portugal.Agricultural and Forest Meteorology 94 , 149-158. https://doi.org/10.1016/S01681923(99)00008-8. 
Gavazzi, M.J., Sun, G., McNulty, S.G., Treasure, E.A., \& Wightman, M.G. (2016). Canopy rainfall interception measured over ten years in a coastal plain loblolly pine (pinus taeda l.) plantation. Transactions of the ASABE $59,601-610$.

Gerrits, A., Pfister, L., \& Savenije, H. (2010). Spatial and temporal variability of canopy and forest floor interception in a beech forest.Hydrological Processes 24, 3011-3025.

Gerrits, A.M.J., Savenije, H.H.G., Hoffmann, L., \& Pfister, L. (2007). New technique to measure forest floor interception - an application in a beech forest in Luxembourg. Hydrology and Earth System Sciences 11 , 695-701. https://doi.org/10.5194/hess-11-695-2007

Giacomin, A., \& Trucchi, P. (1992). Rainfall interception in a beech coppice (Acquerino, Italy). Journal of Hydrology 137, 141-147.

Guillemette, F., Plamondon, A.P., Prévost, M., \& Lévesque, D. (2005). Rainfall generated stormflow response to clearcutting a boreal forest: peak flow comparison with 50 world-wide basin studies. Journal of Hydrology 302, 137-153. https://doi.org/10.1016/j.jhydrol.2004.06.043

Hankin, B., Metcalfe, P.W., Johnson, D., Chappell, N.A., Page, T.J.C., Craigen, I., Lamb, R., \& Beven, K.J. (2017). In: Flood Risk Management. InTech p. 1-39. https://doi.org/10.5772/intechopen.68677

Hashino, M., Yao, H., \& Yoshida, H. (2002). Studies and evaluations on interception processes during rainfall based on a tank model. Journal of Hydrology 255 , 1-11. https://doi.org/10.1016/S0022-1694(01)00506-6

Holwerda, F., Bruijnzeel, L.A., Scatena, F.N., Vugts, H.F., \& Meesters, A.G.C.A. (2012). Wet-canopy evaporation from a Puerto Rican lower montane rain forest: The importance of realistically estimated aerodynamic conductance. Journal of Hydrology 414, 1-15. https://doi.org/10.1016/j.jhydrol.2011.07.033

Horton, R., E. (1919). Rainfall interception. Monthly. Weather Review 47 , 603-623. https://doi.org/10.1175/1520-0493(1919)47<603:RI >2.0.CO;2

Iroumé, A., \& Huber, A. (2002). Comparison of interception losses in a broadleaved native forest and a Pseudotsuga menziesii (Douglas fir) plantation in the Andes Mountains of southern Chile. Hydrological Processes $16,2347-2361$.

Jones, J. A., and Grant, G. E. ( 1996), Peak Flow Responses to Clear-Cutting and Roads in Small and Large Basins, Western Cascades, Oregon, Water Resour. Res., 32( 4), 959- 974, doi:10.1029/95WR03493.

Jongman, B., Winsemius, H. C., Fraser, S., Muis, S., \& Ward, P. J. (2018). Assessment and Adaptation to Climate Change-Related Floods Risks. In D. Benouar (Ed.), Natural Hazard Science (pp. 1-29). (Oxford Research Encyclopedias). Oxford, UK: Oxford University Press. https://doi.org/10.1093/acrefore/9780199389407.013.278

Keim, R., Skaugset, A., Link, \& T., Iroume, A. (2004). A stochastic model of throughfall for extreme events. Hydrology and Earth System Sciences 8 , 23-34. https://doi.org/10.5194/hess-8-23-2004

Kelliher, F., Whitehead, D., \& Pollock, D. (1992). Rainfall interception by trees and slash in a young pinusradiata d donstand. Journal of Hydrology 131 , 187-204. https://doi.org/10.1016/0022-1694(92)90217-J

Kirby, C., Newson, M.D., \& Gillman, K. (1991). Plynlimon research: The first two decades (Report No. 109 ). Institute of Hydrology, Wallingford, UK, 197p

Klaassen, W., \& Lankreijer, H., Veen, A. (1996). Rainfall interception near a forest edge. Journal of Hydrology 185, 349-361. https://doi.org/10.1016/0022-1694(95)03011-5

Klingaman, N.P., \& Levia, D.F., \& Frost, E.E. (2007). A comparison of three canopy interception models for a leafless mixed deciduous forest stand in the eastern United States. Journal of Hydrometeorology 8 , 825-836. https://doi.org/10.1175/JHM564.1 
Lalic, B., Mihailovic, D., Rajkovic, B., Arsenic, I., \& Radlovic, D. (2003). Wind profile within the forest canopy and in the transition layer above it. Environmental Modelling \& Software 18 , 943-950. https://doi.org/10.1016/S1364-8152(03)00067-9

Lane, S. N. (2017) Natural flood management. Wiley Interdisciplinary Reviews: Water 4 , e1211. https://doi.org/10.1002/wat2.1211.

Lavers, D.A., Allan, R.P., Wood, E.F., Villarini, G., Brayshaw, D.J., \& Wade, A.J. (2011). Winter floods in Britain are connected to atmospheric rivers. Geophysical Research Letters 38 . https://doi.org/10.1029/2011GL049783

Lavers, D.A., Allan, R.P., Villarini, G., Lloyd-Hughes, B., Brayshaw, D.J., \& Wade, A.J. (2013). Future changes in atmospheric rivers and their implications for winter flooding in Britain. Environmental research letters 8 . https://doi.org/10.1088/1748-9326/8/3/034010

Law, F. (1956). Effect of afforestation upon the yield of water catchment areas. Journal of the British Waterworks Association 38 , 489-494.

Lankreijer, H., Hendriks, M., \& Klaassen, W. (1993). A comparison of models simulating rainfall interception of forests. Agricultural and Forest Meteorology 64, 187-199. https://doi.org/10.1016/0168-1923(93)90028-G

Lankreijer, H., Lundberg, A., Grelle, A., Lindroth, A., \& Seibert, J. (1999). Evaporation and storage of intercepted rain analysed by comparing two models applied to a boreal forest. Agricultural and Forest Meteorology 98 , 595-604.

Lewis, J., Reid, L. M., \& Thomas, R. B. (2010), Comment on "Forest and floods: A new paradigm sheds light on age-old controversies" by Younes Alila et al. Water Resourses Research 46 , W05801, doi:10.1029/2009WR008766

Link, T.E., Unsworth, M., \& Marks, D. (2004). The dynamics of rainfall interception by a seasonal temperate rainforest. Agricultural and Forest Meteorology 124, 171-191.

Lopez-Moreno, J. I. S. Begueria \& J. M. Garcia-Ruiz (2006) Trends in high flows in the central Spanish Pyrenees: response to climatic factors or to land-use change? Hydrological Sciences Journal 51:6 , 10391050, DOI: 10.1623 /hysj.51.6.1039

Loustau, D., Berbigier, P., \& Granier, A. (1992). Interception loss, throughfall and stemflow in a maritime pine stand .2. An application of gash analytical model of interception. Journal of Hydrology 138 , 469-485. https://doi.org/10.1016/0022-1694(92)90131-E

Lu, J., Sun, G., McNulty, S.G. \& Amatya, D.M. (2005), A comparison of six potential evapotranspiration methods for regional use in the South Eastern Unites States. Journal of the American Water Resources Association 41 , 621-633. doi:10.1111/j.1752-1688.2005.tb03759.x

Lull, H. W., \& K. G. Reinhart (1972). Forests and floods in the eastern United States, Res. Pap. NE-226, For. Serv., U.S. Dep. of Agric., Washington, D. C.

Massman, W. (1983). The derivation and validation of a new model for the interception of rainfall by forests. Agricultural Meteorology 28 , 261-286. https://doi.org/10.1016/0002-1571(83)90031-6

Matthews, T., Murphy, C., McCarthy, G., Broderick, C., \& Wilby, R.L. (2018). Super Storm Desmond: a process-based assessment.Environmental Research Letters 13(1) , 014024. https://doi.org/10.1088\%2F1748$9326 \% 2 \mathrm{Faa} 98 \mathrm{c} 8$

Mayes, C. (2013). Regional weather and climates of the British Isles - Part 5: Wales. Weather 68 , 227-232.

Met. Office, (2006). MIDAS UK Hourly Rainfall Data. NCAS British Atmospheric Data Centre. Accessed

June 2018. http://catalogue.ceda.ac.uk/uuid/bbd6916225e7475514e17fdbf11141c1 
Met. Office (2018). UK Climate extremes. Accessed June 2018. https://www.metoffice.gov.uk/public/weather/climate-extremes/\#?tab=climateExtremes

Monteith, J. L. (1965). Evaporation and environment. Symp. Soc. Exp. Biol. 19, 205-234.

Moors, E. (2012). Water Use of Forests in the Netherlands, Ph.D. thesis. Vrije Universiteit Amsterdam, Netherlands. 209p.

Morton, F. (1984). What are the limits on forest evaporation? Journal of Hydrology 74 , 373-398. https://doi.org/10.1016/0022-1694(84)90025-8

Muzylo, A., Llorens, P., Valente, F., Keizer, J.J., Domingo, F., \& Gash, J.H.C., 2009. A review of rainfall interception modelling. Journal of Hydrology 370 , 191-206. https://doi.org/10.1016/j.jhydrol.2009.02.058

Newson, M.D., \& Calder, I.R. (1989). Forests and water resources: problems of prediction on a regional scale. Philosophical Transactions of the Royal Society of London. B, Biological Sciences 324 , 283-298. https://doi.org/10.1098/rstb.1989.0049

Pearce, A., Gash, J., \& Stewart, J. (1980b). Rainfall interception in a forest stand estimated from grassland meteorological data. Journal of Hydrology 46 , 147-163. https://doi.org/10.1016/0022-1694(80)90040-2

Pook, E., Moore, P., \& Hall, T. (1991). Rainfall interception by trees of pinus-radiata and eucalyptusviminalis in a $1300 \mathrm{~mm}$ rainfall area of Southeastern New-South-Wales .1. Gross Losses and Their Variability. Hydrological Processes 5 , 127-141. https://doi.org/10.1002/hyp.3360050202

Price, A., \& Carlyle-Moses, D. (2003). Measurement and modelling of growing-season canopy water fluxes in a mature mixed deciduous forest stand, southern Ontario, Canada. Agricultural and Forest Meteorology 119 , 69-85. https://doi.org/10.1016/S0168-1923(03)00117-5

Raupach, M.R. (1979). Anomalies in Flux-Gradient Relationships Over Forest. Boundary-Layer Meteorology 16 , 467-486. https://doi.org/10.1007/BF03335385

Reynolds, C., Irish, A., \& Elliott, J. (2001). The ecological basis for simulating phytoplankton responses to environmental change (PROTECH).Ecological Modelling 140 , 271-291. https://doi.org/10.1016/S0304$3800(01) 00330-1$

Reynolds, E., \& Henderson, C. (1967). Rainfall interception by beech, larch and Norway spruce. Forestry: An International Journal of Forest Research 40 , 165-184.

Robins, P. C. (1969). Comparative Studies of Evaporation fromPinus nigra and Pseudotsuga menziesii, with Particular Reference to Air and Stomatal Resistances. Ph.D. thesis, Univ. London, 151p.

Robinson, M. \& Newson, M.D. (1986). Comparison of forest and moorland hydrology in an upland area. 551 with peat soils. International Peat Journal 1 , 46-48. 552

Rutter, A. (1963). Studies in the water relations of Pinus-Sylvestris in plantation conditions. 1. Measurements of rainfall and interception. Journal of Ecology 51, 191-203. https://doi.org/10.2307/2257513

Rutter, A.J. (1967). An analysis of evaporation from a stand of Scots pine. In: W.E. Sopper and H.W. Lull Eds., Int. Symp. on Forest Hydrology, Pergamon Press, Oxford, pp.403-417.

Rutter, A., Robins, P., Morton, A., \& Kershaw, K. (1972). Predictive model of rainfall interception in forests, .1. derivation of model from observations in a plantation of Corsican Pine. Agricultural Meteorology $9,367-384$.

Saito, T., Matsuda, H., Komatsu, M., Xiang, Y., Takahashi, A., Shinohara, Y., \& Otsuki, K. (2013). Forest canopy interception loss exceeds wet-canopy evaporation in Japanese cypress (Hinoki) and Japanese cedar (Sugi) plantations. Journal of Hydrology 507, 287-299. https://doi.org/10.1016/j.jhydrol.2013.09.053 
Szeicz, G., Endrodi, G., \& Tajchman, S. (1969). Aerodynamic and surface factors in evaporation. Water Resources Research 5 , 380-394. https://doi.org/10.1029/WR005i002p00380

Silva, I.C., \& Okumura, T. (1996). Throughfall, stemflow and interception loss in a mixed white oak forest (Quercus serrata Thunb. ). Journal of Forest Research 1, 123-129.

Simpson, I., Thurtell, G., Neumann, H., Den Hartog, G., \& Edwards, G. (1998). The validity of similarity theory in the roughness sublayer above forests. Boundary-Layer Meteorology 87, 69-99. https://doi.org/10.1023/A:1000809902980

Staelens, J., De Schrijver, A., Verheyen, K., \& Verhoest, N.E.C. (2008). Rainfall partitioning into throughfall, stemflow, and interception within a single beech (Fagus sylvatica L. ) canopy: influence of foliation, rain event characteristics, and meteorology.Hydrological Processes 22 , 33-45. https://doi.org/10.1002/hyp.6610

Stewart, J. (1977). Evaporation from wet-canopy of a pine forest. Water Resources Research 13 , 915-921. https://doi.org/10.1029/WR013i006p00915

Stewart, J.B., \& Thom, A.S. (1973). Energy budgets in pine forest.Quarterly Journal of the Royal Meteorological Society 99 , 154-170. https://doi.org/10.1002/qj.49709941913

Stratford, C., Miller, J., House, A., Old, G., Acreman, M., Duenas-Lopez, M.A., Nisbet, ... Tickner, D. (2017). Do trees in UK-relevant river catchments influence fluvial flood peaks? (Project no. NEC06063). NERC/Centre for Ecology \& Hydrology, Wallingford, UK, 46p.

Thom, A.S., Stewart, J.B., Oliver, H.R., \& Gash, J.H.C. (1975). Comparison of aerodynamic and energy budget estimates of fluxes over a pine forest. Quarterly Journal of the Royal Meteorological Society 101, 93-105. https://doi.org/10.1002/qj.49710142708

Thomas, R.B. \& Megahan, W.F. (1998). Peak flow responses to clear-cutting and roads in small and large basins, western Cascades, Oregon: A second opinion. Water Resources Research 34(12),3393-3403.

Toba, T., \& Ohta, T. (2005). An observational study of the factors that influence interception loss in boreal and temperate forests. Journal of Hydrology 313 , 208-220. https://doi.org/10.1016/j.jhydrol.2005.03.003

van Dijk, A.I.J.M., Gash, J.H., van Gorsel, E., Blanken, P.D., Cescatti, A., Emmel, C., Gielen, .. Wohlfahrt, G. (2015). Rainfall interception and the coupled surface water and energy balance.Agricultural and Forest Meteorology 214 , 402-415. https://doi.org/10.1016/j.agrformet.2015.09.006

Whitehead, P.G., \& Robinson, M. (1993). Experimental basin studies-an international and historical perspective of forest impacts. Journal of Hydrology 145 , 217-230. https://doi.org/10.1016/0022-1694(93)90055$\mathrm{E}$

Wingfield, T., Macdonald, N., Peters, K., Spees, J., Potter, K. (2019). Natural Flood Management: Beyond the evidence debate. Area 51,743-751. https://doi.org/10.1111/area.12535

World Bank (2017). Implementing nature-based flood protection: Principles and implementation guidance. Washington, DC: World Bank. 
figures/Fig1/Fig1-eps-converted-to.pdf 
figures/Fig2/Fig2-eps-converted-to.pdf 
figures/Fig3/Fig3-eps-converted-to.pdf 
figures/Fig4/Fig4-eps-converted-to.pdf 
figures/Fig5/Fig5-eps-converted-to.pdf 
figures/Fig6/Fig6-eps-converted-to.pdf 


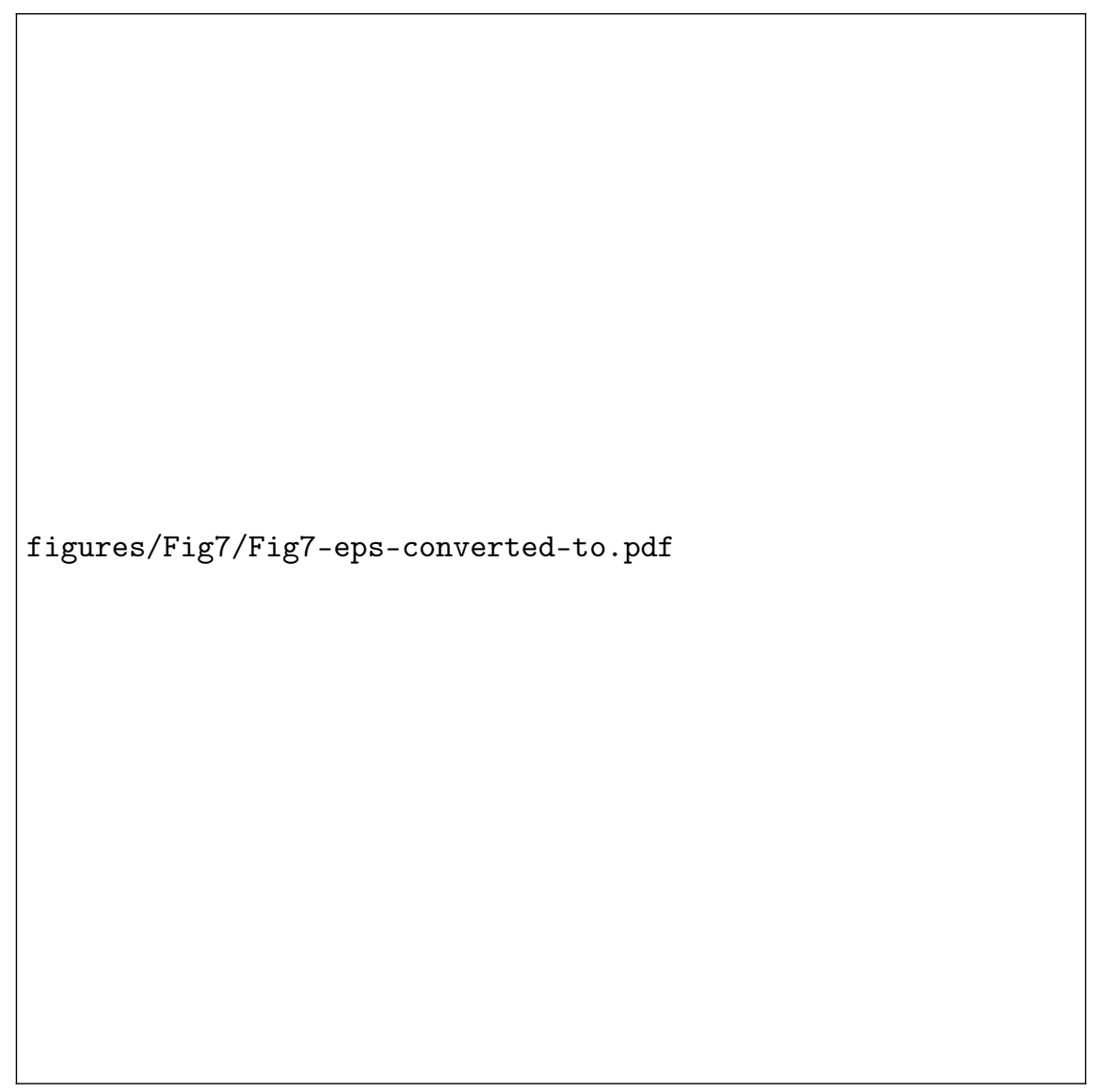

\section{Hosted file}

Table Supp. 1.docx available at https://authorea.com/users/322298/articles/451332-assessingthe-significance-of-wet-canopy-evaporation-from-forests-during-extreme-rainfall-eventsfor-flood-mitigation-in-mountainous-regions-of-the-uk

\section{Hosted file}

Table Supp. 2.docx available at https://authorea.com/users/322298/articles/451332-assessingthe-significance-of-wet-canopy-evaporation-from-forests-during-extreme-rainfall-eventsfor-flood-mitigation-in-mountainous-regions-of-the-uk

\section{Hosted file}

Table Supp 3.docx available at https://authorea.com/users/322298/articles/451332-assessingthe-significance-of-wet-canopy-evaporation-from-forests-during-extreme-rainfall-eventsfor-flood-mitigation-in-mountainous-regions-of-the-uk

\section{Hosted file}

Table Supp. 4.docx available at https://authorea.com/users/322298/articles/451332-assessingthe-significance-of-wet-canopy-evaporation-from-forests-during-extreme-rainfall-eventsfor-flood-mitigation-in-mountainous-regions-of-the-uk 
figures/FigSupp1/FigSupp1-eps-converted-to.pdf 
figures/FigSupp2/FigSupp2-eps-converted-to.pdf 